\title{
Pengaruh Pelayanan Publik dan Profesionalisme Perangkat Kelurahan Terhadap Kepuasan Masyarakat
}

\section{The Influence Of Public Service And Profesionalism Village Official On Community Satisfaction}

\author{
Vina Yanti Br Purba* \\ Fakultas Ekonomi, Universitas Muslim Nusantara Al-Washliyah, Indonesia \\ Disubmit: 21 Juli 2021; Diproses: 25 Juli 2021; Diaccept: 12 September 2021; Dipublish: 02 Desember 2021 \\ *Corresponding author: E-mail: 02vinayantipurba@gmail.com
}

\begin{abstract}
Abstrak
Penelitian ini bertujuan untuk mengetahui seberapa besar Pengaruh Pelayanan Publik dan Profesionalisme Perangkat Kelurahan Terhadap Kepuasan Masyarakat Di Kelurahan Batang Terap Kabupaten Serdang Bedagai. subyek penelitian ini adalah masyrakat Kelurahan Batang Terap yang berjumlah 65 orang sampel. Penelitian ini menggunakan metode penelitian kuantitatif. Teknik pengumpulan data pada penelitian ini adalah wawancara dan kuesioner (angket). Observasi dan kuesioner yang diberi skor menggunakan Skala Likert. Teknik pengumpulan sampel menggunakan accidental sampling. Teknik analisis data penelitian ini menggunakan analisis deskriptif dan analisis kuantitatif. Hasil penelitian ini menggunakan uji t menunjukkan bahwa Pelayanan Publik berpengaruh terhadap kepuasan masyarakat dengan nilai $4.121>1.998$ nilai signifikan < 0,05 atau 0,000 < 0,05. Sedangkan Profesionalisme tidak berpengaruh terhadap kepuasan masyarakat dengan nilai $1.504<1.998$ terlihat pada nilai signifikan lebih besar dari 0,05 atau 0,138 > 0,05. Berdasarkan perhitungan menggunakan koefisien determinasi nilai Adjusted R Square (R2) adalah 0,785 atau 78,5\% sedangkan sisanya 21,5\% dijelaskan oleh faktor lain yang tidak dimasukkan dalam penelitian ini. Dapat disimpulkan bahwa variabel Pelayanan Publik memiliki pengaruh terhadap kepuasan masyarakat sedangkan variabel Profesionalisme tidak berpengaruh terhadap kepuasan masyarakat di Kelurahan Batang Terap Kabupaten Serdang Bedagai.
\end{abstract}

Kata Kunci : Kepuasan Masyarakat; Pelayanan Publik; Profesionalisme

\begin{abstract}
This study aims to determine how big the influence of public services and the professionalism of village officials on community satisfaction in Batang Terap Village, Serdang Bedagai Regency. The subjects of this study were the people of Batang Terap Village, which amounted to 65 samples. This study uses quantitative research methods. Data collection techniques in this study were interviews and questionnaires (questionnaire). Observations and questionnaires were scored using a Likert Scale. The sampling technique used was accidental sampling. The data analysis technique of this research used descriptive analysis and quantitative analysis. The results of this study using the t test showed that public services had an effect on community satisfaction with a value of $4.121>1.998$ significant value $<0.05$ or $0.000<0.05$. Meanwhile, professionalism has no effect on people's satisfaction with a value of $1.504<1.998$ seen in a significant value greater than 0.05 or $0.138>0.05$. Based on calculations using the coefficient of determination the value of Adjusted $R$ Square (R2) is 0.785 or $78.5 \%$ while the remaining $21.5 \%$ is explained by other factors not included in this study. It can be concluded that the Public Service variable has an influence on community satisfaction while the Professionalism variable has no effect on community satisfaction in Batang Terap Village, Serdang Bedagai Regency.
\end{abstract}

Keywords: Community Satisfaction; Public service; Professionalism Profesionalisme Perangkat Kelurahan Terhadap Kepuasan Masyarakat di Kelurahan Batang Terap Kabupaten Serdang Bedagai. Jurnal Penelitian Pendidikan, Psikologi dan Kesehatan (J-P3K), 2 (3): 223-227. 


\section{PENDAHULUAN}

Kelurahan menurut Undang-undang Nomor 32 tahun 2004 pada pasal 127 tentang Pemerintahan Daerah yaitu Kelurahan dipimpin oleh lurah yang dalam pelaksanaan tugasnya memperoleh pelimpahan dari bupati/walikota. Berdasarkan hal tersebut dapat dipahami bahwa penempatan kelurahan sebagai suatu wilayah kerja yang memiliki organisasi pemerintahan di bawah kecamatan (Bingku et al., 2017). Dengan kata lain bahwa nuansa kelurahan tetap sama yaitu tetap menjadi lini terdepan dalam melaksanakan pemerintahan.

Adapun yang membedakan kelurahan menurut Undang-undang Nomor 5 tahun 1979 dengan UndangUndang Nomor 22 tahun 1999 terletak pada: (1) Kewenangan yang dimilikinya, (2) Perubahan perangkat dari perangkat Pemerintah pusat menjadi perangkat Daerah, (3) Adanya perubahan asas yang dilaksanakan yaitu dari asas dekonsentrasi dan asas desentralisasi menjadi azas desentralisasi. Dengan demikian fungsi adanya perangkat kelurahan sebagai pembantu pemerintah Kecamatan dalam menjalankan tugasnya dalam pemerintahan untuk melakukan pelayanan publik sangatlah vital.

Pelayanan publik merupakan suatu tugas wajib para aparatur pemerintah (perangkat kelurahan) sebagai abdi masyarakat (Arisman, 2016). Pengertian tersebut dapat disipulkan bahwa dalam melaksanakan tugasnya aparatur pemerintah harus senantiasa berusaha melayani kepentingan masyarakat dengan mentaati peraturan yang telah berlaku.

Oleh karena itu, pelayanan publik merupakan suatu hal yang sangat mendasar bagi suatu instansi pemerintahan. Pemerintah sebagai pelayanan masyarakat atau bisa disebut sebagai public servant (Bisri \& Asmoro, 2019) mempunyai suatu kewajiban dan tanggung jawab untuk dapat memberikan pelayanan yang baik dan juga profesional kepada masyarakat.

Administrasi kepemerintahan yang dilaksanakan oleh instansi Pemerintah di Pusat, di Daerah, dan lingkungan Badan Usaha Milik Negara atau Badan Usaha Milik Daerah menggunakan istilah konsepsi pelayanan kepada masyarakat dengan sebutan pelayanan publik (public servis) yang mencakup pelayanan administrasi, perijinan dan pelayanan umum.

Kepuasan pelanggan bergerak ke arah birokrasi pemerintahan dalam menjalankan pelayanan publik, dikarenakan peningkatan kualitas suatu pelayanan publik dalam bentuk pelayanan adalah sangat penting sebagai ujung akhir dari keseluruhan reformasi birokrasi. Oleh karena itu, pelayanan publik yang diselenggarakan oleh sektor publik sampai saat ini masih kurang memuaskan masyarakat.

Pelayanan publik yang dilakukan birokrasi bukan melayani pelanggan (customer) tetapi melayani warga negara (Isa, 2009). Lurah Batang Terap merupakan salah satu Kelurahan yang terletak di Kota Perbaungan sehingga menarik untuk di jadikan objek penelitian dikarenakan di Desa ini banyak warga yang berpenghasilan minim di bawah satu juta sehingga mendorong warga untuk mengurus Surat Keterangan Tidak Mampu. Dimana surat tersebut penting bagi warga sekitar mengingat mahalnya biaya kesehatan dan pendidikan. 
Sebagai instansi pemerintahan yang bertindak sebagai pemberi pelayanan kepada masyarakat umum (Isa, 2009), kantor Lurah Batang Terap memiliki masalah utama yaitu mengenai pemberian pelayanan apakah pelayanan yang diberikan sesuai dengan harapan masyarakat atau tidak, hakikatnya pelayanan yang baik adalah pelayanan yang sesuai dengan harapan masyarakat.

Berdasarkan pemaparan teori serta masalah tersebut maka perlu penelitian terhadap kepuasan masyarakat sebagai tolak ukur untuk menilai tingkat kualitas pelayanan yang diberikan oleh Kelurahan Batang Terap. Di samping itu penelitian terhadap kepuasan masyarakat akan dapat menjadi bahan penilaian terhadap unsur pelayanan yang masih perlu perbaikan dan menjadi pendorong setiap unit penyelenggara pelayanan untuk meningkatkan kualitas pelayanannya.

Berdasarkan dari tema permasalahan yang diuraikan tersebut maka dari itu peneliti ingin menjadikannya sebagai latar belakang pada penelitian ini, yang selanjutnya diangkat dengan judul Pengaruh Pelayanan Publik dan Profesionalisme Perangkat Kelurahan Terhadap Kepuasan Masyarakat di Kelurahan Batang Terap Kabupaten Serdang Bedagai, untuk selanjutnya peneliti tertarik dilanjutkan sebagai objek dan dasar penelitian.

\section{METODE PENELITIAN}

Tipe penelitian yang digunakan adalah pendekatan kuantitatif deskriptif atau korelasi dengan pola kajian korelatif dengan menempatkan variabel penelitian dalam dua kelompok yaitu variabel bebas dan variabel terikat. Variabel bebas $(\mathrm{X})$
Pelayanan Publik dan Profesionalisme dan variabel terikat Kepuasan Masyarakat.

Pelayanan publik merupakan segala sesuatu bentuk kegiatan pelayanan yang dilaksanakan oleh penyelenggara pelayanan publik sebagai upaya pemenuhan kebutuhan penerima pelayanan maupun pelaksanaan ketentuan peraturan perundang-undanganan.

Profesionalisme merupakan suatu pandangan bahwa suatu keahlian tertentu akan diperlukan dalam pekerjaan tertentu yang mana keahlian itu hanya diperoleh melalui pendidikan khusus atau latihan khusus ataupun sesuai. Kepuasan atau ketidakpuasan merupakan suatu perasaan senang atau kecewa seseorang yang berasal dari perbandingan antara kesannya terhadap kinerja produk yang rill/aktual dengan kinerja produk yang diharapkan.

Penelitian ini dilakukan pada 65 masyarakat di Kelurahan Batang Terap Kabupaten Serdang Bedagai yang datang ke kantor lurah untuk mengurus dokumen penting dan dinyatakan sebagai sampel yang sesuai dengan penelitian ini. Teknik sampling yang digunakan adalah accidental sampling. Alat pengumpulan data berupa Skala Likert. Analisis data dilakukan dengan teknik korelasi Product Moment dari Pearson Menggunakan bantuan program SPSS.

\section{HASIL DAN PEMBAHASAN}

Berdasarkan hasil analisis dengan metode analisis korelasi $r$ Product Moment, diketahui bahwa ada pengaruh Pelayanan Publik terhadap Kepuasan Masyarakat sedangkan Profesionalisme tidak ada pengaruh terhadap Kepuasan Masyarakat. Hasil analisis diperoleh nilai 
thitung untuk variabel Profesionalisme (X2) sebesar 1.504. maka thitung yang diperoleh lebih kecil dari nilai tabel atau $1.504<1.998$ kemudian terlihat pula bahwa nilai signifikan lebih besar dari 0.05 atau 0,138>0,05 maka H2 ditolak sehingga variabel X2 tidak memiliki kontribusi terhadap Y. Dengan demikian dapat disimpulkan X2 tidak berpengaruh dan signifikan terhadap kepuasan masyarakat.

\begin{tabular}{lllll} 
Model & R & R Square & $\begin{array}{c}\text { Adjusted RStd. Error of } \\
\text { Square }\end{array}$ & $\begin{array}{c}\text { Estimate } \\
\text { 1 }\end{array}$ \\
\hline & $634^{\mathrm{a}}, 402$ &, 383 & 3,13947 \\
\hline
\end{tabular}

Berdasarkan tabel diatas dapat diketahui nilai $\mathrm{R}$ menunjukkan korelasi berganda, yaitu Pelayanan Publik Dan Profesionalisme adalah sebesar 0,634 atau $63,4 \%$. Artinya hubungan erat, semakin besar R berarti hubungannya semakin erat. $\mathrm{R}$ square $\left(\mathrm{R}^{2}\right)$ atau kuadrat $\mathrm{R}$ menunjukkan koefisien determinasi adalah sebesar 0,402 atau $40,2 \%$.

Artinya presentase Pelayanan Publik Dan Profesionalisme Terhadap Kepuasan Masyarakat. Digunakan untuk satu variabel independent. Sedangkan variabel independent lebih dari satu sebaiknya menggunakan adjusted $R$ square. Adjusted $R$ square merupakan nilai $\mathrm{R}^{2}$ yang disesuaikan sehingga gambarnya lebih mendekati mutu penjajakan model dalam populasi. Dari tabel diatas dapat dibaca Adjusted $R$ square $\left(\mathrm{R}^{2}\right)$ adalah 0,785 atau $78,5 \%$ sedangkan sisanya $21,5 \%$ dijelaskan oleh faktor lain yang tidak dimasukkan dalam penelitian ini.

\section{SIMPULAN}

Berdasarkan Uji Kerelasi Product Moment dapat dilihat bahwa Persamaan regresi linier berganda pada penelitian ini yaitu $\mathrm{Y}=\mathrm{a}+\mathrm{b} 1 \mathrm{X} 1+\mathrm{b} 2 \mathrm{X} 2+\mathrm{e}$. Pernyataan ini dibuktikan hasil analisis diperoleh nilai t hitung untuk variabel Pelayanan Publik (X1) sebesar sebesar 4.121 jika dibandingkan dengan nilai tabel yang sebesar 1.998. Maka thitung $>t_{\text {tabel }}$ atau 4.121 $>1.998$ kemudian nilai signifikan $<0,05$ atau 0,000 $<0,05$ maka $\mathrm{H} 1$ diterima sehingga variabel X1 memiliki kontribusi terhadap Y. Nilai $t$ positif menunjukkan bahwa X1 mempunyai hubungan yang searah dengan $Y$.

Jadi dapat disimpulkan variabel Pelayanan Publik berpengaruh secara positif dan signifikan terhadap Kepuasan Masyarakat. Hasil analisis diperoleh nilai thitung untuk variabel Profesionalisme (X2) sebesar 1.504. maka thitung yang diperoleh lebih kecil dari nilai tabel atau $1.504<1.998$ kemudian terlihat pula bahwa nilai signifikan lebih besar dari 0.05 atau 0,138>0,05 maka $\mathrm{H} 2$ ditolak sehingga variabel X2 tidak memiliki kontribusi terhadap Y. Dengan demikian dapat disimpulkan X2 tidak berpengaruh dan signifikan terhadap kepuasan masyarakat.

Nilai f hitung adalah diketahui nilai signifikan untuk pengaruh X1 dan X2 secara simultan terhadap Y adalah $0,000<$ 0,05 dan nilai $\mathrm{F}$ hitung $>$ dari $\mathrm{F}$ tabel atau $20.825>3.14$, sehingga dapat disimpulkan bahwa terdapat pengaruh X1 dan X2 secara simultan terhadap Y.

Nilai $\mathrm{R}$ menunjukkan korelasi berganda, yaitu Pelayanan Publik Dan Profesionalisme adalah sebesar 0,634 atau 63,4\%. Artinya hubungan erat, semakin besar R berarti hubungannya semakin erat. $\mathrm{R}$ square $\left(\mathrm{R}^{2}\right)$ atau kuadrat $\mathrm{R}$ menunjukkan koefisien determinasi adalah sebesar 0,402 atau $40,2 \%$. 
Artinya presentase Pelayanan Publik Dan Profesionalisme Terhadap Kepuasan Masyarakat. Digunakan untuk satu variabel independent. Sedangkan variabel independent lebih dari satu sebaiknya menggunakan adjusted $R$ square. Adjusted $R$ square merupakan nilai $\mathrm{R}^{2}$ yang disesuaikan sehingga gambarnya lebih mendekati mutu penjajakan model dalam populasi. Dari tabel diatas dapat dibaca Adjusted $R$ square $\left(\mathrm{R}^{2}\right)$ adalah adalah 0,785 atau $78,5 \%$ sedangkan sisanya $21,5 \%$ dijelaskan oleh faktor lain yang tidak dimasukkan dalam penelitian ini.

\section{UCAPAN TERIMAKASIH}

Penulis mengucapkan terima kasih kepada Bapak Prayogi Eko Prasetio, S.STP dan seluruh perangkat Kelurahan Batang Terap Kabupaten Serdang Bedagai yang telah banyak membantu dan memberikan informasi kepada penulis. Terima kasih kepada seluruh sampel yang telah memberikan waktunya untuk membantu dan mengisi kuesioner.

\section{DAFTAR PUSTAKA}

Arisman. (2016). Mengukur Kepuasan Masyarakat Dan Kualitas Pelayanan Publik. Artikel Kepuasan Dan Kualitas Pelayanan Publik, 122. https://jakarta.kemenkumham.go.id/downl oad/karya-ilmiah/pelayananpublik/71mengukur-kepuasan-masyarakat-dankualitas-pelayanan-publik/file

Bilgah. 2018. Pengaruh Pelayanan Publik Terhadap Kepuasan Pelanggan Pada Dinas Perhubungan

Bingku, A. E. M., Gosal, R., \& Sambiran, S. (2017). Kinerja Lurah Dalam Meningkatkan Pelayanan Publik di Kelurahan Manente Kecamatan Tahuna Kabupaten Kepulauan Sangihe. Jurusan Ilmu Pemerintahan, 2(2).

Bisri, M. H., \& Asmoro, B. T. (2019). Etika Pelayanan Publik di Indonesia. Journal of Governance Innovation, 1(1), 59-76. https://doi.org/10.36636/jogiv.vii1.298
Isa, R. (2009). Efektivitas Organisasi Kecamatan Dalam Pelayanan Publik Setelah Menjadi Perangkat Daerah. Inovasi, 6, 70-86. https://doi.org/10.1093/oxfordhb/97801995 60530.013.0010

Orvini Oflyanti Buru, Emei Dwinanarhati Setiamandani. 2018. Pengaruh Kualitas Pelayanan Publik Terhadap Kepuasan Masyarakat.

Sedati, Lusia, Abdul Halim dan Retno Wulandari. 2015. Pengaruh Profesionalisme, Etika Profesi, Dan Gender Terhadap Tingkat Materialitas Dalam Pemeriksaan Laporan Keuangan (Studi Empiris Pada Kantor Akuntan Publik Di Malang)

Stevil Debora, Yuni Candra, dan Nurlina. 2016. Pengaruh Pelayanan Prima dan Profesionalisme Kerja Pegawai Terhadap Kepuasan Masyarakat. Kantor Kelurahan Padang Sarai Kecamatan Koto Tangah Padang

Sumbawa, I Gede Benny. 2015. Kualitas Pelayanan Berpengaruh Terhadap Loyalitas Pelanggan Dengan Kepuasan Pelanggan Sebagai Variabel Mediasi 